толерантності та емпатії.

\title{
Література
}

1. Бахтин М. М. Эстетика словесного творчества / сост. С. Г. Бочаров; Текст подгот. Г. С. Бернштейн и Л. В. Дерюгина; примеч. С. С. Аверинцева и С. Г. Бочарова. - М. : Искусство, 1979. - 424 с. - (Из истории сов. эстетики и теории искусства). 2. Декларация принципов терпимости, 1995 [Электронный ресурс]. Режим доступа: http://www.un.org/ru/ documents/decl_conv/declarations/toleranc.shtml 3. Дмитриев Г. Д. Многокультурное образование /Г. Д. Дмитриев. -М. : Народное образование, 1999. - 208 с. 4. Крыжанская Ю. С. Грамматика общения /Крыжанская Ю. С., Третьяков В. П. - Л. : Ленинградский университет, 1990. - 208 с. 5. Садохін А. П. Введение в теорию межкультурной коммуникации / А. П. Садохин. - М. : Высшая школа, 2005. - 310 с. 6. Садохин А. П. Межкультурная компетентность: понятие, структура, пути формирования / А. П. Садохин // Журнал социологии и социальной антропологии. - 2007. - Том Х. № 1. - С. 125-139. 7. Персикова Т. Н. Межкультурная коммуникация и корпоративная культура: [учеб. пособие] / Т. Н. Персикова. - М. : Логос, 2002. - 224 с. 8. Потебня А. А. Язык и народность / А. А. Потебня // Мысль и язык. - М. : Правда, 1989. - 321 с. 9. Тарасов Е. Ф. Межкультурное общение - новая онтология анализа языкового сознания / Е. Ф. Тарасов // Этнокультурная специфика языкового сознания. - М. : Институт языкознания РАН, 1996. - C. 7-22. 10. Everett M. Rogers. Edward T. Hall. and the History of Intercultural Communication:The United States and Japan. / Everett M. Rogers, William B. Hart, Yoshitaka Miike // Keio Communication Review. - 2002. № 24.- P. 3-26. 11. Samovar L. A. Communication between cultures / Samovar L. A., Porter R. E., McDaniel E. R. - Wadsworth : Cengage Learning, 2010. - 411 p.

УДК 331.548:159.9.072

Олена Мурзіна

\section{ДОСЛІДЖЕННЯ ПРОФЕСІЙНИХ ЦІННІСНИХ ОРІЕНТАЦІЙ НА ОСНОВІ МЕТОДИКИ «КВАДРАТ ЦІННОСТЕЙ»}

Мурзіна О. А. Дослідження професійних ціннісних орієнтацій на основі методики «Квадрат цінностей».

У статті розглянуто методику дослідження ціннісних орієнтацій особистості на основі методики «Квадрат цінностей». Поняття «професійні ціннісні орієнтації» для нас означає спрямованість особистості на цілі, засоби та умови професійної діяльності. Особливу увагу зосереджено на анкетуванні курсантів та студентів Запорізького юридичного інституту ДДУВС. У результаті дослідження зроблено висновок, що запропонована методика тестування $\epsilon$ дієвим інструментом для вивчення професійних ціннісних орієнтацій майбутніх фахівців.

Ключові слова:цінності, ціннісні орієнтації, професійні цінності, професійні ціннісні орієнтації, професійна діяльність, «Квадрат цінностей».

Мурзина Е. А. Исследование профессиональных ценностных ориентаций на основе методики «Квадрат ценностей».

В статье рассмотрена методика исследования ценностных ориентаций личности на основе методики «Квадрат ценностей». Понятие «профессиональные ценностные ориентации» для нас означает направленность личности на цели, средства и условия профессиональной деятельности. Особое внимание сосредоточено на анкетировании курсантов и студентов Запорожского юридического института ДДУВС. В результате 
исследования мы пришли к выводу, что предложенная методика тестирования является действенным инструментом для изучения профессиональных ценностных ориентаций будущих специалистов.

Ключевые слова:ценности, ценностные ориентации, профессиональные ценности, профессиональные ценностные ориентации, профессиональная деятельность, «Квадрат цінностей».

Murzina O. A. Research of professional values based on methods «Square of values»

The research methodology of individual's value orientations based on the method «Square of values» has been considered in the article. The concept of «professional value orientations» means for us the orientation of the personality on goals, means and conditions of professional activity. Particular attention is focused on the questionnaire of cadets and students of Zaporozhye Law Institute DDUVS. As a result of research, we came to the conclusion that the proposed testing methodology has an effective instrument for the study of professional value orientations of future specialists.

Key words: values, values based, professional values, professional values based, professional occupation, «Square of values».

За умов політичної, економічної та соціальної напруги в українському суспільстві важливого значення набуває об'єктивна діяльність юристів, що вимагає великих моральних зусиль, професійних навичок, об'єктивного пізнання правових явищ, правової ерудиції та компенсації, знання законів природи, володіння інформацією з актуальних проблем. Така діяльністьможлива на основі сформованих цінностей, які сприяють адекватному сприйняттю особистістю правової дійсності, прийняттю справедливих і законних рішень. Саме цінності людини, які вона послідовно реалізує у своєму житті, є показником iї зрілості як особистості.

Відомо, що професійнадіяльність має подвійний характер: в ній перебувають у діалектичному взаємозв'язку система речей (матеріальний компонент) та система ідей (ідеальний, духовний компонент). Факти свідчать про деструктивні зміни цих компонентів: загальний депрофесіоналізм суспільства, послаблення мотивації навчання студентів та професіонального розвитку спеціалістів, об'єднання цілей їх індивідуальної діяльності тощо. Професійні ціннісні орієнтації (ПЦО) призвані, 3 одного боку, бути інтегруючими засобами, які зв'язують ці компоненти людської діяльності, 3 іншого - відрефлексовані та сформовані в свідомості, повинні бути засобами як професійного вдосконалення спеціаліста, так і самих професій. Таку роль вони відіграють тому, що ціннісні орієнтації- одне з основних структурних утворень зрілої особистості. Саме в них, за словами Б. Ананьєва [1, с. 300], сходяться іï різні психологічні характеристики. Незважаючи на різні підходи до розуміння природи ціннісних орієнтацій, дослідники визнають, що особливості будови і вмісту ціннісних орієнтацій особи зумовлюють іiі спрямованості і визначають позицію людини стосовно тих або тих явищ дійсності. Так само одностайна думка, що ціннісні орієнтації відіграють головну роль у реалізації соціальної (у широкому сенсі) поведінки людини, включаючи диспозицію особи [7, с. 89-105], iї установки [5, с. 361], мотиви [2, с. 158], інтереси [3, с. 173-177] і навіть «сенс життя» [6, с. 247].

Mema cmammi- розробити на допомогу практичним працівникам освіти методику дослідження ціннісних орієнтацій особистості на основі методики «Квадрат цінностей».

За допомогою пропонованої методики нами вивчено сім типів професійних 
цінностей:

- суспільно значущі ціннісні орієнтації (С3);

- орієнтації, пов'язані з змістом праці (ЗП);

- зі статусними досягненнями (СД);

- спрямовані на результат праці (РП);

- пов'язані з можливістю розвитку особистості в процесі професійної діяльності (CP);

- самоствердженням (CС);

- умовами праці (УП).

Ураховуючи предмет нашого дослідження (професійні ціннісні орієнтації), ми розробили критерійні оцінки, що стосуються трьох груп орієнтацій: ЗП, РП, УП. Для оцінки рівня сформованості професійних ціннісних орієнтацій у курсантів та студентів (високий, середній, низький) були розроблені відповідні критерії.

Високий рівень - яскраво виражене прагнення (пошуково-активне ставлення) до професії, якою оволодівають. Активне вивчення задля цього навчальної літератури, інформації про результати діяльності представників певної професії. Самостійний пошук додаткової інформації, активна участь у роботі наукового товариства, семінарів, лабораторно-практичних занять.

Середній рівень- епізодичне, активно-пасивне ставлення до майбутньої професії, участі в роботі наукових товариств, гуртків за інтересами. Вивчення спеціальної літератури, пошук додаткової інформації про спеціальності здійснюється не регулярно. В роботі семінарських, лабораторних занять активності не виявляють.

Низький рівень - байдужість до змісту, умов і результатів роботи за фахом. Важливий лише диплом. Товариства, гуртки, клуби не відвідують. Від виконання практичних завдань ухиляються. Спеціальною літературою не цікавляться. Пасивність на семінарах, практичних заняттях.

Методика дослідження забезпечена такою інструкцією [7, с. 15-19].

Перед Вами бланк, розподілений на квадрати. В кожному квадраті вписано визначену цінність. Спочатку подивимось на колонку 1: у ній 7 цінностей. Виберемо одну - найпривабливішу для вас та поставимо 7 балів у маленький квадратик, розташований у лівому куті великого квадрата. Подивимося на 6 цінностей, що залишилися. Яка з них найбільш приваблива для Вас? Поставте в маленький квадрат оцінку 6. Аналогічно припишіть 5, 4, 3, 2 та 1 балів цінностям, які залишилися, залежно від міри їх привабливості для Вас. Потім подивіться на колонку II та зробіть те ж саме 3 цінностями, внесеними в колонки III, IV, V, VI, VII. Перевірте правильність заповнення маленьких квадратів у всіх семи колонках. Простежте, щоб у кожній 3 них стояли оцінки 7, 6, 5, 4, 3, 2, 1 (у будь-якій послідовності), як, наприклад, $7,6,6,2,2,2,1$.

Тепер знову подивіться на бланк. У ньому є 7 розрядів (VII, IX, X, XI, XII, XIII, $\mathrm{XIV),} \mathrm{у} \mathrm{яких} \mathrm{розташовано} \mathrm{ці} \mathrm{ж} \mathrm{цінності.} \mathrm{Вам} \mathrm{необхідно} \mathrm{оцінити} \mathrm{їх} \mathrm{(але} \mathrm{вже} \mathrm{по}$ горизонталі) та приписати 7 балів найбільш привабливій 3 них для Вас; 6 балівцінності, яка буде обрана другою, і т.д. Оцінку треба поставити в маленькому квадраті, який знаходиться в правому верхньому куті кожного квадрата. Після цього переходьте до оцінки цінності, яка знаходиться в колонці XI, потім X і т.д.

Зробіть, щоб у кожному рядку були оцінки 7, 6, 5, 4, 3, 2, 1.

Перед тим як перейти до опису того, як обробляти цю анкету, зазначимо, що в ній передбачено 7 типів ціннісних орієнтацій (табл. 1).

У «Квадраті цінностей» ці типи ціннісних орієнтацій розташовано в конкретній 
послідовності:

\begin{tabular}{|l|l|l|l|l|l|l|}
\hline С3 & ЗД & СД & РП & СР & СС & УП \\
\hline ЗД & СД & РП & СР & СС & УП & С3 \\
\hline СД & РП & СР & СС & УП & С3 & ЗД \\
\hline РП & СР & СС & УП & С3 & ЗД & СД \\
\hline СР & СС & УП & С3 & ЗД & СД & РП \\
\hline СС & УП & С3 & ЗД & СД & РП & СР \\
\hline УП & С3 & ЗД & СД & РП & СР & СС \\
\hline
\end{tabular}

Таблицяя

Таке розташування цінностей є ключем алгоритму під час оброблення «Квадрата цінностей». Так, у нашому прикладі сумарна оцінка ставлення курсанта та студента до ціннісної орієнтації типу «Суспільно значущі» дорівнює 39 балів:

- користь людям (5+6);

- дотримання прав держави і людей $(1+2)$;

- служба закону, його букві $(1+1)$;

- участь у перебудові суспільства $(1+1)$;

- піклування про людей $(2+5)$;

- значущість праці для суспільства $(5+3)$;

- відповідальність за результат праці (3+3).

Ця оцінка заноситься до спеціальної таблиці:

Табличя 2

Обрана професія (спеціальність)

\begin{tabular}{|l|l|l|l|l|l|l|l|l|}
\hline \multicolumn{1}{|c|}{ Типціннісноїоріснтації } & С3 & ЗД & СД & РП & СР & СС & УП & Сума \\
\hline Кількістьбалів & & & & & & & & 392 \\
\hline Місце зазначенням & & & & & & & & \\
\hline
\end{tabular}

Загальнийбал 392 складається 3 суми балів горизонтальних (сума в кожному рядку 28) в семи рядках $(7 * 28=196)$ та вертикальних $(7 * 28=196)$.

Дослідження проводилися серед курсантів та студентів I та IV курсів Запорізького юридичного інституту ДДУВС.

Результати дослідження наведено в таблиці 3.

Таблиия 3

Ієрархія професійних ціннісних орієнтацій курсантів та студентів інституту

\begin{tabular}{|l|l|l|l|l|l|l|l|l|}
\hline Типціннісноїорієнтації & С3 & 3Д & СД & РП & СР & СС & УП & Сумма \\
\hline Кількістьбалів & 32334 & 28992 & 26641 & 32156 & 22496 & 32366 & 22595 & 177330 \\
\hline Місце зазначенням & 2 & 4 & 5 & 3 & 7 & 1 & 6 & \\
\hline
\end{tabular}

Із таблиці 3 видно, що перше місце в ієрархії професійних ціннісних орієнтаціями курсантів та студентів першого та четвертого курсів посідає самоствердження професійної діяльності (СС). У цій групі цінностей найбільш важливими виявилися: можливість відстоювати власну думку; незалежність; подолання труднощів; самовираження в праці; авторитет; реалізація особистих можливостей; нестандартність мислення.

На другому місці - суспільно значущі (С3) орієнтації курсантів та студентів. Найбільш значимими тут виявилися орієнтації: користь людям; дотримання прав держави та людей;служба закону та його букві; піклування про людей; значущість праці для суспільства; відповідальність за результат праці; участь у перебудові 
суспільства.

Третє місце посідають орієнтації на результат праці (РП), 3-поміж яких найважливішими є такі: успіх у житті; стабільне майбутнє; матеріальне благополуччя; громадське визнання; належні житлові умови; нагороди та заохочення; спокійне життя.

На четвертому місці перебувають цінності зі змістом праці (ЗД). У цій групі цінностей найбільш важливими для курсантів та студентів виявилися: боротьба 3 порушниками закону; широкі контакти з людьми; робота з людьми; побудова версій, моделювання ситуацій; пропаганда законодавства; фізичне напруження, витривалість, воля.

П'яте за значущістю місце зайняли орієнтації курсантів та студентів статусні досягнення (СД): підвищення по службі; авторитет; престиж професії; добра репутація серед товаришів; популярність; керівництво людьми; влада над людьми.

На останньому місці, як засвідчують дані таблиці 2, перебувають орієнтації на розвиток особистості $(\mathrm{CP})$ : розвиток здібностей; розширення світогляду; усебічний розвиток; нові трудові вміння та навички; винахідництво, творчість; гармонійний розвиток; удосконалення духовного світу.

У цілому результати констатувального експерименту свідчать про необхідність спеціально організованої роботи з формування у студентів та курсантів професійних орієнтацій (ЗД, РП, УП). Задля цього нами розробляється відповідна цільова комплексна програма (ЦКП), яке передбачає чітке визначення цілей та засобів їх реалізації по курсах.

Таблиия 4

Типи ціннісних орієнтацій

\begin{tabular}{|c|c|}
\hline $\begin{array}{l}\text { Типи ціннісних } \\
\text { оріснтацій }\end{array}$ & Перелік цінностей \\
\hline $\begin{array}{l}\text { Суспільно значущі } \\
\text { (С3) }\end{array}$ & $\begin{array}{l}\text { Користь людям; додержання прав держави і людей; служба закону, його } \\
\text { букві та духу; участь у перебудові суспільства; турбота про людей; } \\
\text { значущість праці для суспільства; відповідальність. }\end{array}$ \\
\hline Із змістом праці (ЗД) & $\begin{array}{l}\text { Розумове напруження, аналітичність, логічність; пропаганда } \\
\text { законодавства; побудова версій, моделювання ситуацій; робота з людьми; } \\
\text { боротьба з порушниками закону; фізичне напруження, витривалість, воля; } \\
\text { широкі контакти з людьми. }\end{array}$ \\
\hline $\begin{array}{l}\text { Орієнтації } \\
\text { (СД) }\end{array}$ & $\begin{array}{l}\text { Престиж професії; значущість людей; влада над людьми; авторитет; } \\
\text { популярність; підвищення по службі, роботі; керівництво людьми. }\end{array}$ \\
\hline $\begin{array}{l}\text { Орієнтації } \\
\text { результат праці (РП) }\end{array}$ & $\begin{array}{l}\text { Успіх у житті; матеріальне благополуччя; стабільне майбутнє; належні } \\
\text { житлові умови; нагороди та заохочення; спокійне життя; громадське } \\
\text { визнання. }\end{array}$ \\
\hline $\begin{array}{l}\text { Орієнтації на розвиток } \\
\text { особистості (СР) }\end{array}$ & $\begin{array}{l}\text { Гармонійний розвиток; удосконалення духовного світу; нові трудові } \\
\text { вміння та навички; винахідництво, творчість; розвиток здібностей; } \\
\text { розширення світогляду; всебічний розвиток. }\end{array}$ \\
\hline $\begin{array}{l}\text { Самоствердження } \\
\text { професійної } \\
\text { діяльності (CС) }\end{array}$ & $\begin{array}{lcccc}\text { Реалізація } & \text { особистісних } & \text { можливостей; нестандартність } & \text { мислення; } \\
\text { можливість } & \text { відстоювати } & \text { власну } & \text { думку; } \\
\text { самовираження в праці; незалежність. } & & & \\
\end{array}$ \\
\hline Умови праці (УП) & $\begin{array}{l}\text { Ненормований робочий день; робота у здоровому оточенні, атмосфері; робота } \\
\text { в екстремальних умовах; подолання непередбачуваних труднощів; часта зміна } \\
\text { видів діяльності; неспокійна, неритова робота; нестандартність ситуації. }\end{array}$ \\
\hline
\end{tabular}

Запропонована методика тестування є дієвим інструментом, який допоможе викладачам не тільки корегувати навчальний процес, а й узгодити його з виховною роботою, спрямованою на формування професійних цінностей майбутніх спеціалістів. 


\section{Література}

1. Ананьев В. Г. Человек как предмет познания / В. Г. Ананьев. - Л. : ЛГУ, 1968. - 339 с. 2. Асеев В. Г. Мотивация поведения и формирование личности// В. Г. Асеев. - М. : Мысль, 1976. - 158 с. З. Дубровина И. В. Способности и интересы / И. В. Дубровина // Возрастная и педагогическая психология: [учебник]. - М., 1999. С.173-177. 4. Мурзіна О. А. Формування професійних ціннісних орієнтацій у майбутніх правоохоронців : [методичні рекомендації] / О. А. Мурзіна. - Запоріжжя, 2014. - С. 26-32. 5. Надирашвили Ш. А. Установка и деятельность / Ш. А. Надирашвили. - Тбилиси, 1987. - 361 с. 6. Обуховский К.Психология влечений человека: [монография] / К. Обуховский; ред. Б. М. Сегал. - М. : Прогресс, 1972. 247 с. 7. Ядов В. А. О диспозиционной регуляции социального поведения личности / В. А. Ядов // Методологические проблемы социальной психологии. - М. : Наука, 1975. - C. 89-105.

Іванна Размолодчикова

\section{ВПЛИВ ОСВІТНЬОГО СЕРЕДОВИЩА НА СОЩАЛІЗАЦІЮ ОСОБИСТОСТІ МАЙБУТНЬОГО ВЧИТЕЛЯ ПОЧАТКОВИХ КЛАСІВ І ЙОГО ІМІДЖ}

Размолодчикова І. В. Вплив освітнього середовища на соціалізацію особистості майбутнього вчителя початкових класів та його імідж.

У статті розглядається проблема впливу культурно-освітнього середовища на соціалізацію особистості майбутнього вчителя. Розглянуто процеси, що відбуваються, та тенденції, що впливають на соціалізацію особистості вчителя. Індивідуальний імідж розуміється як цілісна система, що складається з компонентів, кожний із яких $\epsilon$ комплексним об'єднанням елементів знань і вмінь.

Ключові слова: соціалізація, культура, освіта, вчитель початкових класів.

Размолодчикова И. В. Влияние образовательной среды на социализацию личности будущего учителя начальных классов и его имидж.

В статье рассматривается проблема влияния образовательной среды на социализацию личности будущего учителя. Рассмотрены процессы и тенденции, которые влияют на социализацию личности учителя.Индивидуальный имидж рассматривается как целостная система, которая складывается из компонентов, каждый из которых является комплексным объединением разных элементов знаний и умений.

Ключевые слова: социализация, культура, образование, учитель начальных классов.

Razmolodchikova I. V. Effect of educational environment on the socialization of personality of a future elementary school teacher and his image.

Article considers the problem of the influence of the educational environment on socialization ofthepersonofthefutureteacher. Here is discusses processes and trends that affect on the socialization of the person teacher. Individual image is regarded as a comprehensive whole, which consists of two major components, each of them being a complex combination of various elements of knowledge and skills.

Key words: socialization, culture, education, primary school teacher.

Однією 3 істотних ціннісних тенденцій сучасного суспільства є орієнтація на образ (ідеал) успішної людини, здатної реалізувати свою життєдіяльність на рівні 